\title{
Perceived Effects of Development-Induced Displacement on Low-Income Households in Addis Ababa
}

\author{
Abduselam Kemal Hussen ${ }^{1}$ and Belay Tefera Kibret ${ }^{2 *}$ \\ ${ }^{1}$ Department of Psychology, Woldia University, Wello \\ ${ }^{2}$ School of Psychology, Addis Ababa University, Addis Ababa
}

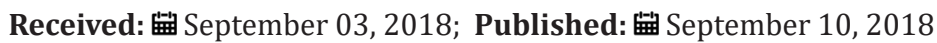

*Corresponding author: Belay Tefera, Department of Psychology, School of Psychology, Addis Ababa University, Addis Ababa

\begin{abstract}
The profile of Addis Ababa city has been changing due to the promotion of privatization, slum area clearance, construction of condominium houses, and conversion of agricultural fields in the suburbs to urban lands. Hundreds of low-income households have been displaced and, as an aftermath, were adversely affected by this development-induced displacement. The objective of this study was to describe and explore the perceived social and psychological effects of the "development-induced displacement" on a sample of Twenty-three purposefully selected participants in Addis Ababa. Data were collected from those low-income households who were originally residing in Kebele houses around Tikur Anbessa Hospital and later resettled into one of the suburbs of Addis Ababa called "Jemo Three Condominium site" through open-ended interviews and questionnaire. As expected, findings have indicated that displacing people from the inner city to new resettlement sites in the outskirts was associated with social breakdowns (such as frustration to form close relationship with neighbors and absence of warm and trusting relationship) as well as psychological problems (like lack of confidence and motivation to earn a living and poor self-esteem). The finding also indicated that the displacement has additionally created loss of jobs, incurred high transport costs, and challenged access to education and healthcare. The damage caused by resettlement on poor resettles far outweighs its benefits and, therefore, the government needs to revisit its housing strategy.
\end{abstract}

Keywords: Displacement; Resettlement; Social wellbeing; Psychological Wellbeing

\section{Introduction}

Internally Displaced People are among the least studied categories of people in the world and, hence, internationally agreed upon definitions for it is yet to come. Developmentinduced displaced persons are among the internally displaced group. Scholars, therefore, used the operational definition for 'Development-Induced-Displaced people as 'persons or groups of persons who are forced to leave their lands or homes or their possessions as a result of development processes that put their livelihoods in danger Pankhurst \& Piguet [1], UN and Habitat [2]. The number of Internally Displaced People seems to be increasing globally as about ten million people enter the cycle of forced displacement and relocation on an annual basis mostly due to development projects. Out of these, urban development projects reportedly cause the displacement of some six million people every year from their lands and homes Cernea [3], Pankhurst \& Piguet [1]. It is widely and increasingly accepted that urbanization is inevitable phenomenon. In developed countries like Europe and North
America urbanization has been a consequence of industrialization and has been associated with economic development. In the developing countries of Latin America, Africa and Asia, urbanization has occurred as a result of high natural urban population increase and massive rural-to-urban migration Brian [4], Minwuyelet [5]. According to Cernea [6], ongoing industrialization and urbanization processes are likely to increase, rather than reduced. As the demands of the urbanizing population increases, notably in Africa and Asia, it is inevitable that the need for infrastructure development will grow enormously and displacement from inner cities is likely to occur on massive scale McDowell [7], Pankhurst \& Piguet [1], World Bank [8]. Development-Induced-Displacement has serious human rights and socio-economic impacts. It breaks up entire communities and families, making it difficult for them to cope with the uncertainty of resettlement. Risks are usually higher for vulnerable groups, such as children, women, poor, the elderly, ethnic minorities, and indigenous people Minyahil [9]. 
Furthermore, Cernea [10] has identified and discussed in detail eight principal risks that lead to the impoverishment of displaced community. These are: landlessness, joblessness, homelessness, marginalization, food insecurity, increased morbidity, loss of access to common property, and community disarticulation. Both global and national experiences show that resettlement usually fails to achieve its objectives UN-Habitat [11].

It is usually unproductive, ineffective, catastrophic, grievous, and environmentally detrimental. As discussed by “...resettlement often leads to impoverishment...and sometimes involves abuse of human rights". According to Pankhurst and Piguet [1], many development programs are often in conflict with the interests of local people worldwide. A number of communities have witnessed serious resource depletion and economic impoverishment as a result of their displacement in the name of 'development'. Feleke [12], Feyera [13], Eyasu [14], Eyob [15] examined the consequences of urban development projects on the lives of people who are evicted from their rural lands and houses. These studies uncovered that, as a result of inadequate consultation and compensation the displaced families are exposed to social and economic impoverishment. The works of Gebre [16], Mengistu [17], Wolde-Selassie [18] vividly depict the absolute failure, harsh and ruinous life experience of resettlers in Ethiopia over previous decades. Gebre [19] has discussed the issue in his report of urban development and displacement in Addis Ababa. He outlined the impact of resettlement projects on low-income households. His research revealed that because of their relocation away from the inner city, most of the displacees experienced different hardships, such as decline/loss of income, poor access of educational and health services, transport problems and breakdown of social networks. Why does resettlement so often go wrong, and end up leaving the resettled people (and often others as well) economically, socially and psychologically worse-off than before? According to Pankhurst and Piguet [1], there seem to be two broad approaches to answering this question: the inadequate inputs approach and the inherent complexity approach. Among these approaches the inadequate inputs approach is evident in the process of Development- Induced Displacement so far conducted in Ethiopia. According to this approach, resettlement goes wrong, principally because of a lack of proper inputs such as legal frameworks and policies, political will, funding, pre-resettlement surveys, planning the displacement ahead, consultation with those to be displaced, careful implementation, and monitoring.

In Ethiopia, urban development appears to be the order of the day and will remain an on- going process for decades to come. There are indications that more new projects and the expansion of existing ones will displace more people. In a televised press conference in the context of the Ethiopian Millennium celebration, the late Prime Minister Meles Zenawi indicated that 70 percent of the houses in Addis Ababa would be demolished and rebuilt. An inadequate master plan, poor housing facilities, environmental problems, and shanty corners, among others, characterize urban centers of developing countries Dierig, [20], Kamete, Tostensen, Tvedten[21], Meheret [22], Potts [23], Rabinovitch [24]. The renewal and development programs of urban areas often target slums and shanty areas normally inhabited by low-income households. Compared to suburbs, income generating opportunities and social services are often concentrated in such areas. Therefore, relocation of low-income households from inner cities to the outskirts would, undoubtedly, affect their livelihoods and informal networks of mutual assistance, their critical coping strategies Lourenço Lindel [25]. It has been widely agreed that people dislocated from inner cities are likely to lose important locational advantages linked to their survival Davidson et al. [26], Gebre [19]. Addis Ababa is in a position that it is not able to accommodate inhabitants due to the substantial flooding of new comers from rural areas and small towns of the country in search of better life. Nevertheless, they usually find themselves in difficult socio-economic circumstances. The number of homeless and those who live in very poor houses is increasing in an alarming rate Gebre [19]. According to a report of 80 per cent of the population in Addis Ababa lives in sub-standard slum housing that needs either complete replacement or significant upgrading. There is a massive demand for serviced, healthy, and affordable housing in the capital. This demand stems both from the current housing deficit and the poor quality of the existing government housing stock (kebele houses) that are beyond repair. The government of Ethiopia estimates that the housing deficit in urban areas is between 900,000 and 1,000,000 units, of which 300,000 units are found in the capital city, Addis Ababa MWUD [27], UN-Habitat [2]. The government also estimates that only 30 per cent of the housing stock is in a fair condition, while the remaining 70 per cent is in need of total replacement.

In response to this challenge, the Ethiopian government outlined an ambitious vision of constructing condominium houses for low and middle-income households and inner-city up grading program since 2005 UN-Habitat [2]. The initial goal of the program, Integrated Housing Development Program (IHDP), was to promote homeownership for low and middle-income households by constructing 400,000 condominium units, reduce unemployment, promote the development of 10,000 micros and small enterprises, enhance the capacity of the construction sector, and regenerate inner-city slum areas. For the purpose of achieving these goals the Addis Ababa city government displaced and displacing many lowincome households from inner city to peripheries of the city. The city is expanding horizontally, and the population is moving to unplanned settlements on the peripheries at the expense of agricultural lands. Since most private investments are highly concentrated around the main urban center, the problem of displacement is becoming a primary concern Hehl \& Stollman [28]. Addis Ababa, the capital of Ethiopia, is undergoing a major transformation as evidenced by the construction of condominiums, road, networks, schools, healthcare institutions, hotels, real estates, banks, shopping centers, and 
many other businesses. There is a sense of jubilation on the part of authorities and the general public with the direction of the urban development policy and the remarkable gains scored thus far. What remains unnoticed, however, is that thousands of people have been displaced and adversely affected by the process of urban development Teshome [29]. The process of relocating people from inner city to new resettlement sites in the outskirts have disrupted the relocatees' business ties with customers, broken their informal networks, caused loss of locational advantages, loss of jobs and incurred high transport costs Gebre [19]. Although the Addis Ababa city administration considers that its land lease allocation system boosts the market value and proper exploitation of urban land, most of its projects are not in accordance with the international and national policies and the norms set by agencies like the UN, the World Bank and the Environmental Protection Authority. The rural people affected by the urban projects are also not actively involved in the assessment, feasibility studies, planning and implementation process. The urban development projects rather have tended to give more attention to local and foreign investors than the urban poor and the peasants who live in the vicinity of the city Melaku [30], Pankhurst \& Piguet [1]. Many other studies focused on the physical and economic impacts of relocation scheme giving emphasis to the housing conditions and the availability of infrastructures. These studies gave little, if any, attention to psychological and social breakdowns that result from displacement. But the present study focused mainly on social breakdowns and psychological disturbances associated with low-income households who were displaced from inner city (around Tikur Anbessa) and located to Jemo Three condominium site which is found in the outskirts (13 kilometers away from the center of the city). This area (Jemo Three) was part of Oromiya region previously. This study focused on lowincome households who were living in Kebele houses paying few birr for house rent (8.6 birr on average per month). People who live in Kebele houses are believed or expected to be relatively poor, and hence, adaptation to new environments would be difficult for them when compared to people who are financially strong.

The available statistics reveal that social services and infrastructural facilities are concentrated in the inner city as compared to suburbs Eyob [15], Gebre [19], Nebiyu [31]. Therefore, relocation of people from the center of a city to the outskirts would lead to social and psychological impoverishment as well as to the decline of access to infrastructural services and facilities. The aim of this study is to explore the aforementioned problems of displacement and to indicate sound strategies to minimize the adverse effects of Development-Induced-Displacement. If the expansion of urban areas and clearing shanty corners continue the same way in Addis Ababa, as expected to be the case, one can imagine that large number of people to be displaced will soon face social and psychological problems. Therefore, research that assesses the social and psychological consequences of urban development projects is expected to play an important role in filling the existing knowledge gap. Therefore, this research is conducted to examine the multifarious effects of development-induced displacement focusing mainly on infrastructural problems, livelihood impacts, social problems, and undesirable psychological effects.

\section{Methods}

Research Setting: this research is conducted in one of the condominium sites found in Nifas Silk-Lafto sub-city of Addis Ababa named as Jemo Three condominium site. Addis Ababa is the economic and political city of Ethiopia, and the melting pot of different nations and nationalities. Almost all the Ethiopian ethnic groups are represented in Addis Ababa due to its position as capital of the country and its location in the geographic center of the country (PEFA, 2008). The city has a population of more than 3.5 million, ten times larger than the second largest city in the country, Dire Dawa. In the past couple of decades Addis Ababa has risen from a city of self-built single-store homes, to a city of skyscrapers. This happened as a result of the inauguration of the Integrated Housing Development Program (IHDP) in 2004. The IHDP is targeted at constructing condominium houses for low income groups through cleaning shanty corners. While the IHDP has the laudable aim of targeting the low-income sector of the population, unfortunately experiences have shown that many poor people are not benefiting from the IHDP due to inability to afford the initial down-payment and monthly service payments. The poorest are primarily excluded from securing a unit because they do not have the financial capacity to pay the required down-payment. Furthermore, the inability to pay the monthly mortgage and service payments forces many households to move out of their unit and rent it out rather than risk losing it through bank foreclosure. The IHDP aims at producing low-cost houses but not low-quality houses. Nevertheless, there have been reports of burst sewerage pipes that leaked through all floors and wide-spread cracking of wall plaster. The expected lifespan of the units is 100 years, although local professionals and residents doubt the validity of these predictions. Construction quality is affected by micro and small enterprises seeking to make additional profit by using cheaper substandard fixtures, such as doors and door handles, as well as the low levels of construction skills and capacity, which is somewhat understandable considering the vast numbers of recently employed inexperienced contractors and builders necessary for projects of this scale. As mentioned earlier the setting of this research is Jemo Three condominium site. The research site is found at the western part of Nifas Silk-Lafto sub-city. Jemo Three is 13 kilometers away from the center of Addis Ababa (Piassa-Georgis). This area was previously governed by Oromiya regional state. Some of the peasants living in the area were displaced and relocated to another area while the rest were given money as a compensation for their land. It is witnessed by people who were living in this area that the land was fertile. Peasants were producing crops like barley and wheat. The peasants were displaced without their willing. It is to this area that people who were living in inner city (around Tikur Anbessa Hospiital) were relocated. Even though peasants were producing sufficient amount of crops from this site, it is not suitable for people who were living 
in inner city and relocated here. The majority of displaced people were earning a living by getting employed in government and nongovernment organizations in inner city. Jemo Three is characterized by relatively poor social services such as transportation, health care and schooling.

Population and Participants: low-income households who were displaced from Tikur Anbessa area and resettled to Jemo Three are the population of this study. These households were living in kebele houses owned by the government before the displacement where they pay very amount of money for house rent. The quality of kebele housing stock is low: typically constructed of mud, wood, and/or discarded materials. Kebele houses are old, having been constructed many decades ago and little to no maintenance has been carried out. Some houses remain with no access to water and electricity, and many do not maintain minimum standards of sanitation. Nevertheless, the social and cultural bonds in their previous village were stronger. They had stronger relationship with people around them. Furthermore, they were economically advantageous before displacement because they were living in inner city where economic activities were better. They lived in this area for more than twenty years on average. Now they are living in condominiums where they were paying 875 birr for house rent on average per month. Data were collected from 23 households who were selected based on snow ball sampling technique. Snowball sampling technique was used since the researcher knows two households who were dislocated from Tikur Anbessa area and relocated to Jemo Three. The process of data collection was started from these two information-rich resettlers. Then, they were asked to locate those households who were displaced from the same area and relocated to Jemo Three.

\section{Tools of Data Collection and Analysis:}

Questionnaire: Since this research was mainly qualitative in nature, open-ended questionnaire was developed by the researchers by relying on the existing literature. The purpose of the questionnaire was to assess the psychological and social impacts of displacement on low income households. It was also intended to compare the difference in infrastructure before and after displacement. The questionnaire had two parts. The first part dealt with demographic variables such as age of the respondents and amount of money paid for house rent before and after displacement while the second part, which was comprised of 7 items, assessed the quality of the respondent's social (e.g., "Do you think that your relationship with your neighbors is warm and trusting?") and psychological life (e.g., "Are you satisfied/dissatisfied with your current setting?") including the quality of infrastructure. Initially, the questionnaire was written in English and then translated into Amharic and it was the Amharic version that was administered finally.

Interview: the interview guide consisting open-ended questions was primarily written by the researchers was translated into Amharic language by the help of two language teachers in Addis
Ababa University. This guide was composed of 9 items assessing the social life (e.g., "Does displacement affect your life? If yes, in what ways?"), psychological life (e.g., "Do you think that displacement affected your self-concept and motivation? If yes, explain how?"), and infrastructural quality (e.g., "Where do you get better access to social services like road, electricity, telephone, transportation, shopping centers, clinic, etc.?") of respondents who were displaced from inner city, due to development-induced displacement, and relocated to the peripheral of the city, specifically to Jemo Three.

Data Analysis: data were collected through interviews and open-ended questionnaires. The data were organized in to different themes and analyzed thematically. Using different methods, informants' sayings were highlighted whenever they have relevance with the topic of the study. Codes were created and brought together for categorizing purposes. Finally, the main themes (based on the category) were identified and the categories were brought together and rearranged under those themes.

Ethical Considerations: During the process of data collection, all necessary precautions were made to ensure that the rights of the sources of data were respected. The data collection instruments were accompanied by informed consent form. The research participants were debriefed concerning the purpose of the research. Besides, the research participants were informed that participation in the research is on voluntary basis and they have all the rights to pull out if they find the data collection or the nature of information is not consistent with their expectations.

\section{Findings}

Characteristics of the Respondents: there were more than sixty households that were displaced from their previous residence and resettled into Jemo Three Condominium site. As indicated in Table 1, data were collected from 23 participants from lowincome households of which $56.5 \%$ were females, $91 \%$ were aged more than 34 years, and almost all of them have lived for more than 30 years in their previous residence. More importantly, the greater majority (78\%) have expressed that they were displaced without consent. Interview results also confirm this observation. For example, a 64 years old woman expressed this discontent as follows:

Table 1: Characteristics of the respondents.

\begin{tabular}{|c|c|c|c|}
\hline Items/ variables & Options & Freq. & Percent \\
\hline Gender & Proportion of women & 13 & 56.5 \\
\hline \multirow{2}{*}{ Age in years } & $>45$ years & 12 & 52.0 \\
\cline { 2 - 4 } & $35-45$ years & 9 & 39.0 \\
\cline { 2 - 4 } & $<35$ years & 2 & \\
\hline $\begin{array}{c}\text { Number of years lived in } \\
\text { previous residence }\end{array}$ & 40 years and above & 17 & 73.9 \\
\cline { 2 - 4 } & $30-39$ years & 6 & 26.1 \\
\hline \multirow{2}{*}{$\begin{array}{c}\text { Consent during } \\
\text { displacement }\end{array}$} & $\begin{array}{c}\text { Displaced with } \\
\text { consent }\end{array}$ & 5 & 21.74 \\
\cline { 2 - 4 } & $\begin{array}{c}\text { Displaced without } \\
\text { consent }\end{array}$ & 18 & 78.26 \\
\hline
\end{tabular}


a) Unless forced, nobody wants to get detached from his/ her home where he/she has lived for many years. Nobody wants to leave a home we have been grown up, learnt, and passed through huge life experiences... (A woman interviewee No. 6, age 64).

b) A 51-years-old woman interviewee also expressed, “...if you ask me how I left my old and lovely home, I will definitely tell you that I was forced by groups of youngsters who were given the task of destroying shanty corners (our old homes). They used to threaten us frequently to move to this new site as soon as possible."

c) A response obtained from another male interviewee aged 61 years also illustrates the same idea. "We were not happy by getting separated from our previous homes, though the aim of the government was development".

Infrastructural Concerns: Data obtained from the research participants of the study clearly showed that there were noticeable differences in availability of regular and adequate services of electricity and water before resettlement (at participant's previous residences) and after resettlement (at participant's current residences, Jemo Three). For example, an interviewee said, "there is slight difference in my previous and current residences, but concerning water supply the two areas are incomparable. At Jemo Three, we get water two or three days a week. We get water at mid night, if you are able to wake up at about 12:00PM or 1:00AM o'clock" (male, age 51). Another relatively younger interviewee (Female, aged 36 years) responded as follows:

...there are huge differences between electricity and water services in my previous and current houses. I wash my cloths once or twice in one month here (new residence) due to shortage of water, but I usually wash once every week at Tikur anbessa (previous village). I learnt how much water is important in once life in practice (though I know it theoretically) at Jemo Three. I started to use water very economically. If I fail not to use economically I must collect water in bucket from very far area and carry the bucket up on to the third floor. The supply of electricity is relatively better than that of water supply at Jemo Three, although, it is worse when compared to the supply of electricity at Tikur anbessa. Here, electric power disappears once or twice a day.

Table 2: perceived infrastructural services of participants before and after displacement.

\begin{tabular}{|c|c|c|c|c|}
\hline Items & \multicolumn{2}{|c|}{ Previous Residence } & \multicolumn{2}{c|}{ Current Residence } \\
\hline Items & Freq. & percent & Freq. & Percent \\
\hline Better electricity supply & 18 & 78.3 & 2 & 8.7 \\
\hline Better water supply & 20 & 87.0 & - & - \\
\hline $\begin{array}{c}\text { Better option for } \\
\text { schools }\end{array}$ & 23 & 100 & - & \\
\hline $\begin{array}{c}\text { Better option for health } \\
\text { care centers }\end{array}$ & 23 & 100 & - & \\
\hline
\end{tabular}

Similarly, responses obtained from the questionnaire revealed that there were better electricity and water supply in their previous than current residences. Among the 23 respondents who filled in the questionnaire, three of them responded that the supply of electricity and water in their previous and current residences was similar. The responses of the rest 20 participants are given in Table 2. As indicated in Table 2, nearly all respondents were saying that their previous residence was better in electricity supply $(78.3 \%)$, water supply (87\%), options for their children's schools (100\%), and health care centers $(100 \%)$.

Interviewees were also complaining about the distance of the site from the center of the city, which incurs them extra transportation cost:

My previous living site was found at the center of Addis Ababa. I was surrounded by Merkato, Legehar, Piassa, Mexico, Abinet, Autobus tera (bus station), etc. Look at those beautiful areas. You can get everything you need in your life (clothes, food items, goods) simply by moving towards these locations with very few amounts of money, or you can even go on foot. Now, I have to, at least, pay more than 20 birr to go to Merkato. I should have to go to the center of the city, Mexico for instance, to buy things I need because goods and food items are relatively more expensive here when compared to their cost at the inner city. Furthermore, things you need are not sufficiently found here (male, age 61).

Another interviewee explained the distance of Jemo Three from the center of the city and problems associated with transportation as follows: My neighbors who were displaced like me were resettled to better sites. I am not lucky by having thrown to this site. It is too far from inner city and the environment is ugly. I think you too agree with my idea. Isn't it? I will never like this site because it will never get improved or will take very long period of time. I have to leave my home very early in the morning, like about 11:30 - 12:00 o'clock due to the reason that he road from the center of the city to my house usually gets overcrowded. Likewise, I need to stop my job early in the afternoon, for instance at about 10:30 so that I could get back to my house before the road once again get congested. What bothers me is not only about the congestion of the road but also about the extra amount of money I am asked on a taxi. We are asked to pay more than the limit set by the transport authority" (male, age 50 years).

Finally, the data collected concerning the provision of schools and health care centers at respondent's previous and current residences revealed that there was significant difference in the number and quality of schools and health care centers. The data showed that respondents were surrounded by various health care centers and hospitals in their previous residences. They were receiving medical services at different government health care centers (Tikur Anbessa hospital, Zewditu hospital, Teklehaimanot health center), but today, in their new village, there is only one government health center. This was substantiated by the following quote. "Recently, I started to frequently pray to God not to get me sick. You know why? Last time (she attempted to recall the exact time, but she couldn't) I went to wereda 02 health care center (a health center around Jemo 1) with one of my neighbor. We went 
there because she was sick. The long queue of patients I observed on that day made me pray to God to stay me healthy. There are many clinics for those who are rich. These clinics are not affordable by poor people like me and my neighbor." Data about the availability of schools for children of displaced parents showed that parents were experiencing shortage of schools for their children. "In my previous village I can send my children to different schools because we had various options. The schools were also relatively closer to our homes. Here we have very limited options and simultaneously the few available schools are located at distant areas" (Interviewee No. 11, male, age 56). The other interviewee (male, age 49) also reported that there was shortage of schools and parents were suffering a lot. "...of course, the schools found in our area are meant for rich people because they charge you a lot of money. We cannot send our children to these schools. Affordable schools are found a bit far from Jemo Three." The researcher of this study observed that the schools found around the study area were not intended for those poor displaced people. These schools were charging not less than 600 birr per month for a child. The researcher also noticed that some parents were sending their children to schools that are found in their previous village. These parents had to wake up and force their children wake up very early in the morning so that they could send their children to schools before the roads get crowded. Responses obtained from questionnaire similarly showed that there was a difference in the number of health care centers and schools for children of displaced parents. Resettlers were asked to compare where they found relatively better health care centers and schools for their children. Those participants who had no children to send to school were asked simply to compare the number of schools in their old and current living areas.

According to the observation of the researcher, the presence of two churches (St Gebriel and St Mary) at Jemo Three condominium site was the only thing that made Christian respondents feel good and a little bit happier. There was no worshipping area for Muslims at Jemo Three, but there is a mosque around Jemo Two Site which is not too far. Concerning worshipping areas, respondents were comfortable, though, there were differences in the number of churches and mosques between the previous and current residences of resettlers. "We (Christians) have two churches both of which are very close to our homes. St Gebriel Church is at the back of my home." The other participant explained about worshipping area in her site as "Even though, I don't want to compare the number of churches and mosques, there is no single mosque at which we pray at least one prayer a day, leave-alone five prayers. There were not less than 5 mosques around Tikur Anbessa" (Christian and Muslim women interviewees of age 41 and 48 respectively).

Livelihood Impacts: Responses obtained from the interview indicated that poor people who were displaced have many concerns:

a. "I am one of those whose life is messed up as a result of Development-Induced-Displacement. I am unable to deal with the required monthly mortgage repayment. Due to this reason,
I'm forced to beg and pay the monthly cost of my house not to lose it through foreclosure by commercial bank of Ethiopia" (agd 55 years).

b. "The lives of many poor and those who were unable to cope up with the ever-changing condition of life are being affected as a result of displacement from their village and being resettled to the outskirts of the city. I and many others are unable to meet our needs. My life has been affected because my home cannot accommodate my previous income generation activity. Previously I bake bread and injera for sale. The lack of my previous income source put me under extra financial pressure. No schools around for our children and there are insufficient employment opportunities for youngsters when compared to our previous site" (aged 56 years).

Many of the respondents were earning a living from selling different goods, for instance, charcoal, vegetables and fruits such as tomato, potato, onion, etc. in their previous village. They were buying these fruits and vegetables from Piassa-atkilt tera with very cheap price. Atkilt tera was very close to their previous residence. It was not more than 2.5 kilometers for which they were being charged less than two birr for a taxi. But unfortunately, they are located far from the inner city, as a result of Development-Induced-Displacement where different goods for consumption and infrastructural services were not easily and closely available. Atkilt tera is very far from Jemo Three (more than fifteen kilometers). It costs them above ten birr (huge money, if their poverty is considered) to arrive at Atkilt tera with taxi. In addition to its distance there was no sufficient transportation system and it was an area where taxi drivers frequently violet the rules/tariff set by transport authority. They usually got charged above the tariff. Due to this and other similar factors, the overwhelming majority of respondents indicated that their income is significantly declining. As a result, respondents were encountering economic and psychological problems as mentioned by one of the informants:

a) My previous house was closer to church, and market places. I just go to Markato and Atkilt tera, buy onion and tomato with Birr 20.00, display it in front of my house and then sell it and make a profit. But, our present location is detached everything; what can you work and earn in this wilderness environment. Rich men may establish a business but poor people like me are getting hard time. You should wake up early in the morning to take a bus to Markato; taxi is even hard to think about (43 years old interviewee No 23).

b) Furthermore, respondents indicated that the cost of their new houses was another factor that exacerbated their poverty. They were asked to pay between Birr 20,000.00 up to $40,000.00$, depending on the number of bedrooms, to take their new houses. As already mentioned above, almost all of the participants of this study were poor and had no reliable daily/ monthly income. Some of them had paid the initial payment 
(20\% of the total cost of the house) by begging from religious institutions while some others paid by asking from their relatives. The six interviewees in Table 3 explained this issue as: "I and my neighbor, Weizero Zeynaba, were forced to move from one church/mosque to another to collect the money that was required for the initial payment $(18,000$ and 27,000 birr respectively). Finally, both of us managed to collect sufficient amount of money for the $20 \%$ down payment."

Table 3: Housing payment of participants before and after displacement.

\begin{tabular}{|c|c|c|c|}
\hline Participants & $\begin{array}{c}\text { Previous } \\
\text { house rent }\end{array}$ & $\begin{array}{c}\text { Current house } \\
\text { monthly } \\
\text { payment }\end{array}$ & $\begin{array}{c}\text { Type of the } \\
\text { house }\end{array}$ \\
\hline 1 & 24 & 932 & one bed room \\
\hline 2 & 4 & 765 & Studio \\
\hline 3 & 5 & 765 & Studio \\
\hline 4 & 5 & 465 & studio \\
\hline 5 & 4 & 1787 & two bed rooms \\
\hline 6 & 5 & 982 & one bed room \\
\hline 7 & 5 & 465 & Studio \\
\hline 8 & 12 & 1064 & one bed room \\
\hline 9 & 10 & 1064 & one bed room \\
\hline 10 & 12 & 465 & Studio \\
\hline $\begin{array}{c}\text { Average house } \\
\text { rent }\end{array}$ & Birr 8.60 & Birr 875.40 & \\
\hline
\end{tabular}

Though the initial 20\% was paid, the participants were worried and challenged with the amount of money to be paid monthly for twenty years to reimburse the remaining $80 \%$ of the cost of their houses along with the interest. As it can be referred to in Table 3, they were paying very small amount of money for house rent before displacement (about Birr 8.60). After displacement they owned a house but were asked to pay nearly 100 times per month (i.e. an average of Birr 875.4 0. This dramatic increase in expenses has occurred in the face of a decline in income and rising standards of living in Addis Ababa. Because of these challenges, many condominium owners were forced either to sell their house or rent it and then live in a house with lower rent so that they can make a living with the difference earned. The other lesson taken from this research was the inability of some respondents to adjust to the life styles that are expected from someone who leaves on apartment houses. The life style of people who were living in old kebele houses made of wood and iron sheets were different from those who live on large apartments. Some of these problems were observed while they were slaughtering, traditional injera baking, washing clothes, and boiling coffee. The life in apartments was found in convenient to carry out these activities in a traditional way. In the same way, the UN-Habitat (2011) reported that the building designs of condominium houses in Addis Ababa do no respond to occupants' customary activities such as preparation of traditional injera, bread, and slaughtering of animals. These activities require sufficient space for large ovens and open areas. Due to lack of sufficient space in the condominium units, the above-mentioned activities were being undertaken in circulation areas, which caused inconveniences for neighbors.

Social Wellbeing: The data collected concerning the number of intimate neighbors, level of social security, and warm and trusting relationship that displaced people experienced revealed that they have found it difficult and frustrating to form close relationship with others in their new residence when compared to their residence before displacement. The data also showed that intimacy with their previous neighbors was stronger than the current one. A response from 38-year-old man which was taken from the interview strengthens this idea. "There were so many people around me when I was there (old residence) and I had reliable friends too. All those my friends and others whom I know were resettled to different condominium sites, though, it is not clear for me that the benefit of dispersing people who have been living together apart. I found it so difficult to form and maintain relationship with my new neighbors. I think everybody is not happy to carry on his/her life without having any relationship with neighbors." Furthermore, the way a man of age 49 responded clearly shows that those who were resettled to Jemo Three area were unable to connect to people around them. "I had smart link with those people around me in my previous home. Our relationship was interesting. You Know that we used to borrow and give goods and food items (even injera)? I can leave my children with my neighbors so that they can take care of them when I had to move out of Addis Ababa or when I was sick. Doing this is totally impossible here. I don't know what would likely to happen in the future. I hope things will get better."

In the same vein, resettlers had many people to talk to and to listen at before resettlement than after resettlement. They had many people alongside them to share their day-to-day concerns before displacement. They have found very difficult to open up when they want to talk to their new neighbors. The current political instability in the country have made people stay away from one another and exacerbated the loneliness of people living in condominium houses. "I am a social animal. As a social animal I have to get someone to whom I express my day to day concerns. I need to have someone whom I trust. As you are observing I am very old person (approximately above 70). All human beings need to have good neighbors. For old and poor people like me the need will be higher. Many of us have not yet established good relationship with people around us" ( $4^{\text {th }}$ interviewee, male). The following quote which was taken from an interview conducted with a woman interviewee of age 46 revealed that people who were displaced from inner Addis Ababa and relocated to outer part of the city were in an isolated life condition. Truly speaking, I and those who are displaced from inner city are experiencing harsh and difficult conditions in so many ways. For instance, I know only three persons on this building (there are 30 homes on the building of which 11 were empty) and our relationship is not more than greeting each other. I think it was ten days before that I heard someone shouting and looking for help on our building. I wanted to get out and help the person but I preferred to stay at my home. I did not 
know whether that person received any help or not. This did not happen in my previous residence. We know each other very well and help one another. The condition of our life and the quality of our relationship before and after displacement are incomparable. Responses obtained from questionnaire in Table 4 also indicated that respondent's relationship with neighbors before displacement was sincere and trusting. The following table vividly depicts the differences in the quality of the participant's relationship at their previous and current residence.

Table 4: Perceived social support of the participants before and after displacement.

\begin{tabular}{|c|c|c|c|c|}
\hline \multirow{2}{*}{ Items } & \multicolumn{2}{c|}{$\begin{array}{c}\text { Previous } \\
\text { residence }\end{array}$} & \multicolumn{2}{c|}{$\begin{array}{c}\text { Current } \\
\text { residence }\end{array}$} \\
\cline { 2 - 5 } & Freq. & $\%$ & Freq. & $\%$ \\
\hline $\begin{array}{c}\text { I have someone whom I drink } \\
\text { coffee with. }\end{array}$ & 22 & 95.6 & 5 & 22 \\
\hline $\begin{array}{c}\text { There are people who visit me } \\
\text { when I/member of my family get } \\
\text { sick. }\end{array}$ & 23 & 100 & 3 & 13 \\
\hline $\begin{array}{c}\text { I have neighbors who help me } \\
\text { when I am in a difficult situation. }\end{array}$ & 19 & 82.6 & 2 & 9 \\
\hline $\begin{array}{c}\text { I have someone from whom I } \\
\text { borrow things I need. }\end{array}$ & 22 & 95.6 & - & - \\
\hline $\begin{array}{c}\text { I have someone to whom I share } \\
\text { my concerns. }\end{array}$ & 20 & 87 & 3 & 13 \\
\hline $\begin{array}{c}\text { I have neighbors with whom I } \\
\text { celebrate holidays. }\end{array}$ & 23 & 100 & 5 & 22 \\
\hline
\end{tabular}

In relation to resettles participation in social roles such as idir, $i k u b$, and mahber; data showed that displaced people had better and interesting participation in social activities in their previous village than in the current residence. The majority of respondents reported that they did not fit well with people around them. They had no social partners at their current residence and hence have poor participation in social activities taking place in their village. I know nobody here. There is no interaction among people in this village because everybody spends his/her time in his/her own closed doors. There is no one I know to the south, north, east and west of my home. I doubt if I could get someone who would bury my body (male interviewee of age 48). In an interview conducted with a 55-year-old male participant, social roles that link people together such as idir and mahber, are absent in their new village. "Although, it is our responsibility to form relationship with our new neighbors and participate in various social roles, currently, we are not in a position of doing this. This could be due to the fact that we afraid one another so that nobody is willing to take the initiation. I came to Jemo Three nine months before. There was one person on that building (demonstrating the building) who was trying to talk to us so that we could begin knowing and visiting each other. Nevertheless, there is no idir and other social activities in this area." Furthermore, a relatively young participant explained the absence of participation in various social activities. "In our previous village we have so many reliable neighbors from different groups of people. We have good relationship with Muslims, youths, elderly, employed, unemployed, and with other categories of people. If someone needs help due to illness, poverty (of course all of us are poor), and death of relatives we really spend our time, money, and energy to help our neighbor who is in need. Wow! That was very sensational. I think I will never and ever come across that type of life here after. As you see here (in her new village), most of the doors are closed and locked. Nobody is willing to visit his/her neighbors. Our culture and religion encourage us to visit our neighbors and strengthen our social relationship. I, sometimes, feel as I am not living with Ethiopians as Ethiopians are good at social life. I think this (poor social relationship) is the result of modernization" (a woman interviewee No. 21, age 38). Responses obtained from questionnaire in Table 5 revealed similar results. Participants who were displaced as a result of development and resettled far from the center of the city were not participating in social activities and the presence of reliable individuals was poor as indicated in the Table 5.

Table 5: social engagements of participants before and after displacement.

\begin{tabular}{|c|c|c|c|c|}
\hline \multirow{2}{*}{ Items } & \multicolumn{2}{|c|}{$\begin{array}{c}\text { Previous } \\
\text { residence }\end{array}$} & \multicolumn{2}{c|}{$\begin{array}{c}\text { Current } \\
\text { residence }\end{array}$} \\
\cline { 2 - 5 } & Freq. & $\mathbf{\%}$ & Freq. & $\%$ \\
\hline 1. I participate in Idir. & 23 & 100 & - & - \\
\hline 2. I participate in Mahiber. & 17 & 73.9 & 7 & 30.4 \\
\hline $\begin{array}{c}\text { 3. I have good communication with } \\
\text { my neighbors. }\end{array}$ & 22 & 95.6 & 2 & 9 \\
\hline $\begin{array}{c}\text { 4. There are elderlies who could } \\
\text { mediate during conflict. }\end{array}$ & 18 & 78 & 2 & 9 \\
\hline
\end{tabular}

Psychological Wellbeing: According to a response obtained from an interviewee (Male, aged 61 years), "We were nothappy by getting removed from our previous homes, though the aim of the government was development. Here, there are no worshipping areas (mosques), schools for our children, and so on. These were some of the reasons that made us resist the displacement." Data collected revealed that respondents were not satisfied with the process of the displacement and resettlement since it was conducted without their consent. They were also dissatisfied with the new environment, transportation costs, absence/shortage of worshiping areas, and the likes. Furthermore, the new area requires new living condition. The environment was not suitable for some typical life activities of the respondents, for instance, slaughtering purpose, washing clothes, and the likes. These factors led respondents to problems of adaptation to the new environment. In fact, data revealed that resettlers' were more satisfied with their new homes than with their previous old homes because the buildings were attractive and eye catching than their previous old homes. The following quotes were taken from the interviews conducted with three interviewees. "Our earlier houses were very small in size and built of wood and cardboard. Members of more than 5 houses were using a single toilet in common so that we sometimes stand in a queue. My new house has three rooms and I am using my own toilet alone. Don't try to compare those shanty houses with these beautiful buildings." 
The second interviewee responded: "Even though I love my house I don't like this area. The weather is too cold here." Lastly, the third interviewee replies as follows. "Of course, there is a huge difference between my previous home and my new home. Home alone cannot generate satisfaction. Satisfaction is obtained through the combination of various things" (male and female interviewees No. $4,14, \& 23$ respectively).

Responses obtained from questionnaires and interviews indicated that many respondents' effort to live a kind of life they need was not successful after resettlement. Almost eighty percent of the participants reported that they are losing confidence and motivation in their struggle to live a better life. The following quote clearly shows that some of the participants were losing interest and motivation in their day-to-day life activities. "I was very strong person. I wake up very early in the morning. But now, I do not want to even get out of my bed. My interest to go to employment is declining from time to time" (a man of 47 years). This kind of psychological impact emanated from the feeling that they were displaced without their consent and due to the fact that they were relocated to the outskirt of a city. Data collected about loneliness and rejection indicated that most of the respondents reported that they did not fit well with the people and the community around them in their new village. Resettlers did not feel attached to the people around them after resettlement. "When I walk out of my home, after few strides, there were many people who usually greet me and whom I greet, but here (in her new house) I found no one to say 'good morning/ good afternoon' even after travelling remarkable distance" (woman interviewee of age 39). A response obtained from an interview held with another woman who was 44 fortifies that participants were isolated from the community. "When I wake up from a sleep I usually hear noise of children, neighbors, and noise from cars (before resettlement). Here (after resettlement), you hear nothing. Life in condominium houses is so difficult for me because nobody is conscious of you. Nobody knows whether you are happy or not; whether you are fine or not; whether you need help or not." Likewise, responses obtained from questionnaire revealed that many of the respondents were experiencing the feeling of isolation and that of rejection. Some of them felt that they were rejected from the larger community. The aim of the questionnaire was to compare the quality of psychological variables before and after displacement as given in the table below. Equally speaking, many respondents reported that their circle of friends and acquaintances were too limited after displacement and hence they were experiencing a feeling of loneliness. They have no confidants to share their social, psychological and life issues. One of the male informants aged fiftysix speaks out as: "We are thrown away as a dust as if we were not created from mankind. I know not more than six individuals here." The other interviewee also strengthened the idea as follows: "It has been ten days since I got a visit by someone in this new site. Nobody knocked at my door these days. If I want to talk to someone I have to go to other condominium sites where my previous neighbors were relocated (people living in the same area were relocated to different and far away sites after displacement) or I have to go to my old village so that I would share my concerns and inner feelings" (11th interviewee, male, age 56).

Data obtained from questionnaire about loneliness and lack of confidants to share problems in life reveals similar results with that obtained from interviews. Although, almost all respondents reported that they were not suffering from loneliness before displacement, $74 \%$ of the respondents indicated that they were experiencing a feeling of loneliness after displacement, while the rest $26 \%$ explained that they were in a feeling of companionship. Concerning the availability of confidants to discuss problems with, the data showed that $87 \%$ of the displaced people indicated that they had no one close to them to whom they share their concerns at their new residences, though; the majority of them had confidants at their previous residents. The other $13 \%$ reported that they had confidants both at their previous and current residents. Respondents were also asked about the feeling of frustration and hopelessness. Responses obtained from the interviews revealed that people who were displaced from inner city and relocated to remote areas were experiencing frustration, negative attitude about themselves, as well as hopelessness. Here after I would have no hope. Early in the morning I go to church and when I come back to my home I spend the rest of the day sleeping. It is better to die than to live in such a miserable condition (64 years old, male interviewee, No.22). A woman interviewee of age 49 presented her feeling as follows. "Previously (before displacement) we spend our spare time with our neighbors because there were many people around us. As you see here (demonstrating at the building on which she is living) there are only six houses who are not reserved. The other 24 houses are occupied by at least one household, i.e. there are at least 24 individuals currently living on this building. I have a relatively better relation with individuals living on these two rooms (indicating at the two rooms beside her home on the same floor). Therefore, I am not comfortable with this kind of life style. To be honest with you, I am in a position to leave this area. I will rent my home and scape out of this frustrating and hopeless life. It is very recently that I learnt that our culture (collectivist culture) is very important for our health and day-to-day activities." Correspondingly, another participant who was living on the same building but different floor described his wellbeing as "I was a very happy person when I was around kebele 44 (one of the kebeles found in her previous village). The reason was that I was living a relatively joyful life before I was forcefully displaced from my home in which I lived for nearly 30 years. Although my previous home is not comparable with this beautiful home (the previous home had only one room and very old), it was my home in which I gave birth for all my children. The lesson I learnt from my recent life is that, it is not the beauty and quality of home that makes people satisfied and happy; rather it is the quality of your relationship and your mental state. I can't adjust myself to this village forever" (53-yearold, woman interviewee, No. 9). In the same vein, responses obtained from the questionnaire revealed that the percentage 
of the participants' feelings of hopelessness and frustration after displacement was significantly higher when compared to their feelings of frustration and hopelessness after displacement as indicated in the table below.

\section{Discussion}

Forced displacementarises from the need to build infrastructure for new industries, irrigation schemes, transportation highways, power generation dams, or for urban developments such as hospitals, schools, and airports. Such programs are indisputably needed. They improve many people'slives, provide employment, and supply better services. But the involuntary displacements caused by such programs also create major impositions on some segments of the population. According to Cernea [10], displacement leads to social disarticulation. If a community is displaced it tears apart the existing social structures. "It breaks up families and communities; it also dismantles patterns of social organization. From the findings of this research, one can clearly observe that displacing people from their habitual areas breaks up the social relationship and kin ties. Many resettlers reported that their social networks have broken down. Almost all respondents of this research reported that there was significant difference in their social wellbeing before and after displacement. They had satisfying connections with people around them in their previous village. There number of people they usually visit and visited by before displacement was relatively better. The finding further indicated that the social relationship of displaced people is weak not only in terms of the number of people they have contact with but also in terms of closeness to people around them in their new village. The participants made a point that they had no close and trusting relationships with neighbors in the new village (after displacement). Similarly, it was obtained from the finding that participants did not have someone to talk to and to listen at.

The other interesting result of this research, in relation to social life, was the issue of Idir and Mahber. Idir and Mahber are among the many socially constructed roles in many parts of Ethiopia that are meant for the purpose of helping the needy and strengthening social bond. Their main purpose is to link members of the community together so that they would help each other when something good (for instance, marriage) or bad (for instance, death) happens. As the finding indicated resettler's participation in Idir and Mahber, and in other similar social roles, in their previous setting was incomparable with their participation after they got displaced from inner city. The finding boldly indicated that due to lack/shortage of social roles and weak interest to participate, resettlers were experiencing poor social wellbeing. In the same vein, Pankhurst and Piguet [1] made a point that many 'development' programs are often in conflict with the interests of local people worldwide. A number of communities have witnessed serious resource depletion, economic, as well as psychological impoverishment as a result of their displacement in the name of 'development.' Lourenço- Lindel [25] also added that relocation of low-income households from inner cities to the outskirts would, undoubtedly, affect their livelihoods and informal networks of mutual assistance. Furthermore, development- induced-displacement affects coping strategies of people who are displaced from the homes in which they have been living for several years and relocated to new home and new environment. This is consistent with the findings of this research. According to this research, people who were displaced from their previous homes and environment (Tikur Anbessa area) and relocated to Jemo Three (new site) were experiencing psychological problems. Many relocatees are experiencing psychological problems such as lack of positive attitude about themselves, problems related to adaptation to the new environment, a feeling of despair, and inability to lead responsible life. The researcher of this study believed that one of the factors for the poor psychological wellbeing of resettlers, in addition to displacement, was the social breakdown indicated above. The other factors that weakened psychological wellbeing of resettlers was the cost of the houses. It was already discussed in the 'Introduction' section that resettlers were unable to afford the initial down-payment and monthly service payments since they were economically poor. Furthermore, questions associated with the quality of the buildings affected psychological wellbeing of participants [32,33].

\section{Conclusion}

Displacement as the result of urban expansion and 'slum clearance' has been increasing rapidly worldwide and is becoming a significant phenomenon particularly in the large cities of the developing world. As the demands of the urbanizing population increases, notably in Africa and Asia, it is inevitable that the need for infrastructure development will grow enormously and displacement is likely to occur on massive scale World Bank [8],McDowell [7], Pankhurst \& Piguet [1]. As the research findings of this study revealed, most people's livelihoods were affected by displacement programs. Resettlement requires careful and systematic planning particularly in the selection of sites and verification of different infrastructure and social services notably in terms of health and education. Resettlers were brought to the site (Jemo Three) before clinics, schools, and transportation services were not sufficiently arranged. Addis Ababa city administration has to learn from such mistakes for displacements and resettlements to be carried out in the future. Many respondents explained the displacement process as forced displacement. Consent from resettlers should be secured because much of the literatures suggest that forced relocation is more likely to be damaging to poor people's livelihood prospects than it is to improve them Cernea [10], Pankhurst \& Piguet [1]. The damage caused by resettlement far outweighs its benefits and the vast resources wasted on the various programs would have been more profitably employed elsewhere.

\section{Recommendations}

i. Adequate planning and preparation for displacement is vital from the part of the government.

ii. Displacees should be consulted and participated in the plan and also in the process of displacement.s 
iii. Some infrastructures, if not adequate, such as electricity, transportation, clinics, and schools have to be built in the new environment before relocating people.

iv. It is better to give displacees chance of choosing among the available sites for resettlement than displacing them by force.

\section{References}

1. Pankhurst A, Piguet F (2004) People space and the state: Migration, Resettlement and Displacement in Ethiopia. Proceedings of the Workshop held by The Ethiopian Society of Sociologists, Social Workers and Anthropologists and the UN Emergencies Unit for Ethiopia. Addis Ababa, ESSSWA.

2. UN-Habitat (2011) Condominium housing in Ethiopia: European Commission, The Integrated Housing Development Programme. United Nations Human Settlements Programme: Nairobi, Kenya.

3. Cernea M (1995) Bridging the Research Divide: Studying Refugees and Development Oustees, in T Allen (Eds.) In: Search of Cool Ground: War, Flight and Homecoming in Northeast Africa, London.

4. Brian Lund (1996) Housing problems and housing policy. New York, USA.

5. Minwuyelet M (2004) City, Squatter Settlement and Policy Implication in Addis Ababa: The Case of Kolfe Keranio Sub City. Ethiopian Journal of Science and Humanities 2(2): 50-79.

6. Cernea M (1999) Why economic analysis is essential to resettlement: training on the protection of IDPs development-induced displacement.

7. Mcdowell C (1996) Understanding Impoverishment: The Consequence of Development Induced Displacement: Berghahn Books, Providence.

8. World Bank (1995) Resettlement and Development: The Bankwide Review of Projects Involving Involuntary Resettlement. The World Bank, Washington D.C, USA.

9. Minyahil Gatew (2011) Socio-Economic Impacts of Development Induced Displacement: The Case of Sebeta Town. Addis Ababa University, School of Social Work, Unpublished MA Thesis, Ethopia.

10. Cernea M (2000) Risks, safeguards and reconstruction: a model for population displacement and resettlement, in M Cernea, C McDowell (eds), Risks and Reconstruction: Experiences of Resettlers and Refugees, USA.

11. UN-Habitat (2007) Situation Analysis of Informal Settlements in Addis Ababa. Cities without Slums Program: Addis Ababa Slum Upgrading Program. United Nations Human Settlements Program: Nairobi, Kenya.

12. Feleke Tadele (2004) Urban Development and the Displacement of Rural Communities Around Addis Ababa. In Alula Pankhurst and Francois Piguet (Eds.), People, space and the state: Migration, Resettlement and displacement in Ethiopia. Addis Ababa: Department of Sociology and Social Anthropology.

13. Feyera Abdessa (2005) Urban Expansion and the livelihood of the Periurban Agricultural Communities: The case of Addis Ababa. MA thesis: School of Graduate studies college of developmental studies (CDS), Addis Ababa University.

14. Eyasu Shishigu (2007) The impact of urban expansion on the livelihood of peri-urban farming communities in Alamgena town. MA thesis of Regional and Local Development Studies (RLDS). Addis Ababa University, Ethopia.

15. Eyob Alemayew (2010) Urban expansion and its socio-economic and environmental effect on the farming communities: The case of Meri. MA thesis. Addis Ababa University, Ethopia.
16. Gebre Yntiso (2009) Why Did Resettlement Fail? Lesson from Metekel. In Alula Pankhurst and Francois Pigeut (eds). Moving People in Ethiopia, Development Displacement and the State. Eastern Africa Series, Addis Ababa.

17. Mengistu W (2005) Effects of Resettlement Schemes on the Biophysical and Human Environments.

18. Wolde Selassie Abbute (2009) Social Impact of Resettlement in the Beles Valley. In Alula Pankhurst and Francois.

19. Gebre Yntiso (2008) Urban Development and Displacement in Addis Ababa: The Impact of Resettlement Projects on Low-Income Households: Eastern Africa Social Science Research Review 24(2): 53-77.

20. Dierig Sandra (1999) Urban Environmental Management in Addis Ababa: Problems, Policies, Perspectives, and the Role of NGOs. Institute of African Affairs, Hamburg, Germany.

21. Kamete Amin, Arne Tostensen, Inge Tvedten (2001) From Global village to Urban Globe. Urbanization and poverty in Africa: Implications for Norwegian Aid Policy. Chr Michelsen Institute.

22. Meheret Ayenew (1999) The City of Addis Ababa: Policy options for the governance and management of a city with multiple identity. FSS Discussion Paper no. 2 Addis Ababa: Forum for Social Studies.

23. Potts Deborah (1997). Urban lives: Adopting new strategies and adapting rural links. In Carole Rakodi (ed). The urban challenge in Africa: Growth and management of its large cities. United Nations University Press, Tokyo, Japan.

24. Rabinovitch Jonas (1998) Global, regional and local perspectives towards sustainable urban and rural development. In Edesio Fernandes (Eds.). Environmental Strategies for Sustainable Development in urban Areas: Lessons from Africa and Latin America. Ashgate Publishing Ltd, Aldershot, England.

25. Lournço Lindel Ilda (2001) Social networks and urban vulnerability to hunger: Arne Tostensen, Inge Tvedten, Mariken Vaa (eds). Associational life in African cities: Popular responses to urban crises. Nordiska Afrikainstitute, Stockholm, Sweden.

26. Davidson Forbes, Zaaijer Mirijam, Peltemburg Monque, Rodell Mike (1993) Relocation and resettlement manual: A guide to managing and planning relocation. Rotterdam: Institute for Housing and Urban Development Studies.

27. Ministry of Works and Urban Development /MWUD/ (2008). Integrated Housing Development Program of the Federal Democratic Republic of Ethiopia. African Ministerial Conference on Housing and Urban Development, AMCHUD, Abuja, Nigeria.

28. Hehl R, Stollman J (2010) New Towns for the 21 $1^{\text {st }}$ Century: The Planned vs. the Unplanned City. New-Town-To-Be: Kotebe Hana Mariam. An Urbaninform.net Test-site in Addis Ababa. SUN Architecture and authors, Amsterdam, pp. 234.

29. Teshome $\mathrm{T}$ (2008) Managing Ethiopian Cities in an Era of Rapid Urbanization. Appraisal of housing typologies in Addis Ababa. IHS, Eburon Delft, p. 45.

30. Melaku Habtewold (2009) The Economic and Socio-Cultural Consequences of Condominium Housing in Addis Ababa: A case study of Kirkos sub-city.

31. Nebiyu Baye (2000) The Impact of Development-Induced Urban Resettlement Scheme on Relocated Households: The case of Sheraton Addis Hotel Project. Addis Ababa University, Unpublished MA Thesis, Ethiopia.

32. Beeker Cohen (1997) Urban Fields in Africa in the workshop on urban fields of Ethiopia. Ministry of Public Works and Urban Development, Addis Ababa, Ethiopia. 
33. Pankhurst A (2009) Revising Resettlement under Two Regimes in Ethiopia: The 2000s Programme Reviewed in the Light of the 1980s Experience. In Alula Pankhurst and Francois Pigeut (eds). Moving

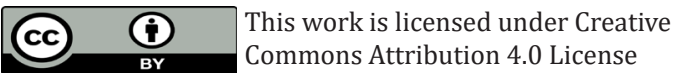

To Submit Your Article Click Here: Submit Article

DOI: $10.32474 /$ SJPBS.2018.01.000108
People in Ethiopia, Development Displacement and the State. Eastern Africa Series, Addis Ababa, Ehtiopia.

\begin{tabular}{|l|l|}
\hline SJPBS & $\begin{array}{c}\text { Scholarly Journal of Psychology } \\
\text { and Behavioral Sciences }\end{array}$ \\
Assets of Publishing with us
\end{tabular}

